\title{
Technology-Driven FDI by Emerging Multinationals in Europe
}

\author{
Cristina Chaminade, CIRCLE, Lund University, Sweden
}

Roberta Rabellotti, Università di Pavia, Italy

SINCE THE TURN OF THE CENTURY, we have witnessed unprecedented international growth of foreign direct investments (FDI) by emerging economy multinational enterprises (EMNEs). In 2013, FDI from developing and transition economies reached the record level of $\$ 460$ billion, corresponding to 39 percent of global outflows, up from 16 percent in 2007 before the financial crisis (UNCTAD, 2014). This shift in the origin of FDI has occurred in parallel with a rise in the proportion of technology-driven FDI (TFDI) from emerging countries particularly aimed at augmenting their technological capabilities through mergers, acquisitions, and greenfield investments abroad. Europe is one of the most important recipients of technology-driven investments from EMNEs. Both the change in the origin as well as in the nature of FDI poses some challenges to the international business community. Some of the critical questions to tackle are:

- Do these investments imply a loss of technological competitive edge in the European firms when they are acquired by EMNEs? Do we observe systematic asset stripping strategies? Or, on the contrary, such investments can create mutual benefits both for the investors and for the economies and the firms they invest in?

- Do international investment agreements and national policies influence the impact of EMNEs investments? Can trade authorities minimize the negative impact and strengthen the positive consequences of such investments? What can be learned from the empirical evidence so far?

This short article highlights the results of a three-year research project (2011-2014) aimed at understanding the dynamics and consequences of FDI and TFDI by EMNEs in Europe, with a particular focus on investments from India and China. TFDI are defined as foreign direct investments undertaken predominantly with the aim of accessing and/or learning to master technologies that the investing company does not have access to before and/or of generating new knowledge.

The results are grounded on a database built within the project (Emerging Multinationals Events and Networks DATAbase; EMENDATA), which contains all the investment deals — greenfield investments, mergers \& acquisitions, and minority investments - by emerging market multinationals (low- and middle-income countries) in the EU-27 between 2003 and 2011. ${ }^{1}$ The analysis of the database has been complemented with in-depth interviews in firms with TFDI in Europe, as well as with interviews to policy makers. The main findings are summarized below. ${ }^{2}$

\section{Characteristics of the Investments}

When we consider all the investment by emerging economies in Europe, China, and India are clearly the most important investors, closely followed by Russia (Figure 1). Approximately 29 percent of all inward investments from emerging countries into Europe come from India and around 21 percent from China. ${ }^{3}$ Their investments are strategically targeted to certain countries and sectors. In terms of countries of destination, UK is the most important destination, followed by Germany and at some distance by France, Spain, and The Netherlands. In terms of industries, Chinese firms mainly invest in manufacturing sectors like electronics, industrial machinery, communication, and the automotive industry, while Indian MNEs invest in service industries and in the pharmaceutical sector.

Figure 1 - Emerging countries FDI to Europe by entry mode (2003-2001) (\# deals)

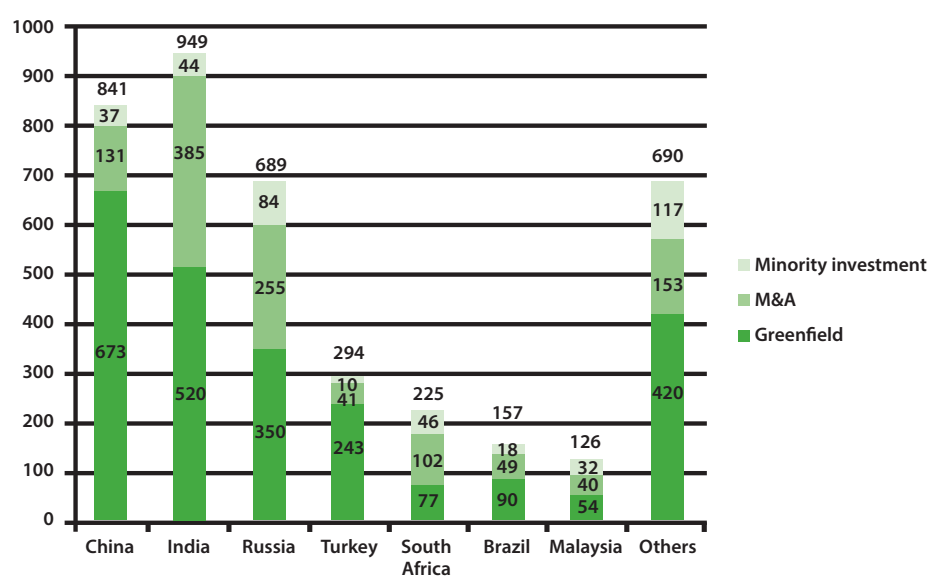

Source: EMENDATA

TFDIs from EMNEs are mainly directed to existing specialized technological hubs in high-income countries (e.g., investments in the automotive sector go to Stuttgart in Germany and to Turin in Italy and those in renewable energies such as wind choose central Denmark). Our findings show that agglomeration economies play a key role in attracting investments from emerging economies, which tend to concentrate in regions or areas with a massive presence of firms in the same industries (Amighini \& Franco, 2013).

While most investments by emerging multinationals in Europe take the form of greenfield ( 80 percent of Chinese deals and more than 50 percent of those from India) (Figure 1), mergers and acquisitions tend 
to be associated with investments from more innovative companies. ${ }^{4}$ This means that EMNEs, especially in technology-intensive industries, acquire other companies in order to access technologically advanced assets not available at home (Amendolagine, Cozza, \& Rabellotti, 2014).

When the objective is accessing technological competences rather than a customer base or an established brand name, Chinese and Indian MNEs prefer less control of the acquired companies (Piscitello, Rabellotti, \& Scalera, 2014). ${ }^{5}$ Indian firms go as far as maintaining the acquired firm as a separate entity to preserve the brand value and penetrate European markets. In one interviewed Indian automotive company, the headquarters decided to maintain the new investment totally independent from the group with R\&D centre in Germany and manufacturing plants both in Germany and in India, preserving the well-known German brand and the original customer network. But this is not a unique case. Our findings show similar strategies for investments in clean-tech (windmills) in Denmark and ICT in France. In the case of Chinese acquisitions, the degree of independence of the subsidiary is highly related to the competences of the acquiring firm: when the acquirer has limited technol-

ogy competences, full autonomy is usually attributed to the subsidiary in the R\&D field. Differently, when the Chinese investor has complementary technology competences, the subsidiary R\&D activity is closely guided by the headquarters and there is intense collaboration between the acquirer and the acquired firm, as shown in various cases in clean-tech and in the automotive industry (Chaminade, 2015). ${ }^{6}$

\section{Impact of the Investments}

The vast literature on direct and indirect spill overs has shown that MNEs are in general reluctant to engage in interactive learning with indigenous firms due to their lower absorptive capacity, the lack of differentiation between firms and the goods that they supply, and the fear of losing knowledge (see among others D'Costa, 2006; Dunning \& Narula, 2004; Dunning, 1993; Lall \& Narula, 2004; Narula \& Marin, 2005). However, TFDIs from emerging economies are quite different because they are aimed at acquiring technological capabilities. In this case, it is the host country that owns advanced technological capabilities of interest to the MNEs.

As an increasing number of firms from emerging countries invest in Europe, worries abound over the potential negative impact of such investments on the local economies. Some fear that Chinese, Indian or other EMNEs will simply take over local companies, exploit their technology, and leave without creating lasting benefits for employment and economic growth in Europe. But are these concerns justified, or should FDI from emerging economies be seen in a more positive light?
Based on interviews with the headquarters and subsidiaries of Chinese and Indian multinationals in Europe, we have observed a high diversity in the impact of TFDls in Europe and no generalized predatory behaviour. More specifically, we have identified five possible impacts on the existing assets: (1) killing, (2) stripping, (3) withering, (4) maintaining, and (5) development. ${ }^{7}$ In several cases the investment has had a positive effect on the European subsidiaries in terms of augmenting their technological capabilities (i.e., asset development). For instance, this happens in some Chinese cases, particularly, but not exclusively, in the clean-tech industry. There are two examples of Chinese subsidiaries in which the headquarters have continued supporting investments in R\&D and the development of new technological solutions in their subsidiaries in Denmark. An Indian company has acquired a German company in Dortmund, which is a global leader in the field of emission controls, with an R\&D lab of more than 150 employees.

The absence of a generalized predatory behaviour is also confirmed by a survey undertaken in Germany and Italy on MNEs from advanced countries and EMNEs investing in the machinery industry, concluding

\section{(s) With a focus on Brazil, India and China, we bave also investigated if cross-border collaborations bring about better innovations comparing the value and the characteristics of cross-border and domestic patents}

that the latter are more likely to engage in local innovation networks and create win-win situations in terms of mutual learning than the first ones (Giuliani, Gorgoni, Günther, \& Rabellotti, 2014).

With a focus on Brazil, India and China, we have also investigated if cross-border collaborations bring about better innovations comparing the value and the characteristics of cross-border and domestic patents $^{8}$ (Giuliani, Martinelli, \& Rabellotti, 2014). The results suggest that cross-border inventions are more rewarding than domestic ones, as they produce higher value patents in terms of forward citations as well as more general patents. This means that innovations based on international collaborations are likely to influence the development of subsequent inventions across a variety of technological fields. We also find that cross-border inventions have lower market scope compared to domestic patents (i.e., protection applies to a smaller number of countries), which suggests that international collaboration is a strategy adopted by EMNEs not to enter potentially new markets but rather to increase the future impact of their innovative activities.

Our cases also show that the final result in terms of impact is clearly mediated by the time horizon as well as by the management skills. We have found that it may take several years to achieve a positive impact in terms of augmenting technological capabilities and increasing the 
patent portfolio and its quality. A medium- to long-term strategy to maintain operations in Europe is needed as it is clearly acknowledged by a clean-tech Chinese firm interviewed observing that "the development of technology is really a long term process."

With regard to managerial skills and international experience, our cases suggest that some of the common pitfalls that often compromise the positive impact of investments are the lack of awareness of the cultural differences and of the gap in technical competences between the headquarters and the subsidiary. For example, in one the investigated acquisitions both the subsidiary and the headquarters indicated that the technological gap between their competences was so substantial that the headquarters could not understand neither the potential technologies that the subsidiary was able develop or the importance for the development of cutting-edge technologies of the local networks of suppliers and customers of the acquired firm. As a consequence the acquired firms suffered from a substantial loss of technological capabilities in the years that followed the acquisition shifting down from world leading innovation to intermediate innovation. ${ }^{9}$

\section{Policy Implications for Europe}

The European integration project is deeply rooted in the liberal economic approach, which emphasizes the benefits resulting from open and integrated markets, not only for goods and services but also for capital and this is reflected in the EU policy toward foreign investments which is one of the most liberal regimes in the world (Dantas \& Meyer, 2014). However, the context in which these regulations were developed has changed, as we have argued earlier. With the rise of FDI flowing from emerging economies to advanced countries, the EU and its member states are suddenly finding themselves in the position of host countries and there are emergent calls for restrictions in clear contrast with the currently open and liberal regime in cases in which security, environmental and social objectives may be compromised,

Our findings suggest that the impact of EMNEs investments can be positive when TFDI are embedded in the host country networks and foster R\&D efforts. For policymakers, this requires efforts in the creation of R\&D incentives and networking opportunities involving foreign investors and the host actors. This would reduce predatory behaviour and open up opportunities for advanced host country managers and entrepreneurs to learn from new investors, leading to valuable knowledge spillovers to the benefit of local firms in the medium and long term.

With respect to investment policies, policy makers in Europe are no longer able to focus one-sidedly on the interests of investors and outbound FDI. In negotiating international investment agreements, they are required to balance the interests of investors with other policy objectives emerging from various domains, including security, environmental, labour, competition/anti-trust and industrial policy. Some of the emerging challenges for the EU regulations are the investor-state dispute settlements, the investments by organizations with strong government links and the investments in sensitive industries and technologies which may require, in the future, a more selective policy for investments (Dantas \& Meyer, 2014).

Finally, our interviews suggest that rather than trade and investment policies, other policies have a stronger influence on the final impact of the investments, notably labour and migration rules as well as IPR regulations. More flexibility in labour rules as well as supportive migration policies - granting work permits to facilitate the short-term mobility of personnel between headquarters and their subsidiaries - were often mentioned by the firms interviewed as cornerstones for the sound functioning of the investments in the short and long term.

\section{References}

Amendolagine, V., Cozza, C., \& Rabellotti, R. 2014. Chinese and Indian multinationals: A firm-level analysis of their investments in Europe. Papers in Innovation Studies, 2014/27, Lund University, CIRCLECenter for Innovation, Research and Competences in the Learning Economy.

Amighini, A. A., \& Franco, C. 2013. A sector perspective on Chinese outward FDI: The automotive case. China Economic Review, 27: 148-61.

Chaminade, C. (Ed.) 2015. Technology-driven FDI by emerging multinationals in Europe. Lund: Lund University.

Chaminade, C., Hansen, T., Parthasarathy, B. 2015. The impact of knowledge seeking strategies by EMNEs in Europe: A typology. Circle Papers in Innovation - Lund University. http://www2.circle.lu.se/ publications/working-papers.

D'Costa, A. P. 2006. Exports, university-industry linkages, and innovation challenges in Bangalore, India. World Bank Policy Research Working Paper 3887.

Dantas, E., \& Meyer, N. 2014. The changes in the institutional frameworks for investment in Europe in a context of increasing technologyoriented foreign direct investment from emerging economies. Mimeo.

Dantas, E., \& Meyer, N. 2014. Changing institutions governing investment in Germany: the role of rising technology-oriented foreign direct investment from emerging economies. Mimeo.

Dunning, J., \& Narula, R. 2004. Relational assets: The new competitive advantages of MNEs and countries. In J. H. Dunning \& R. Narula (Eds), Multinational and industrial competitiveness: A new agenda. Northampton, MA: Edward Elgar.

Dunning, J. H. 1993. Trade, location of economic activity and the multinational enterprise: A search for an eclectic approach. London: Routledge. 
Giuliani, E., Gorgoni, S., Günther, C., \& Rabellotti, R. 2014. Emerging versus advanced country MNEs investing in Europe: A typology of subsidiary global-local connections. International Business Review, 23(4): 680-691.

Giuliani, E., Martinelli, A., \& Rabellotti, R. 2014. Is co-invention expediting technological catch up? A study of collaboration between emerging country firms and EU inventors. Papers in Innovation Studies, 2014/25, CIRCLE-Center for Innovation, Research and Competences in the Learning Economy, Lund University.

Lall, S., \& Narula, R. 2004. Foreign direct investment and its role in economic development: Do we need a new agenda? The European Journal of Development Research, 16(3): 447-464.

Narula, R., \& Marin, A. 2005. Exploring the relationship between direct and indirect spillovers from FDI in Argentina. MERIT-Infonomics Research Memorandum Series 2005-024.

Piscitello, L., Rabellotti, R., \& Scalera, V. 2016. Chinese and Indian acquisitions in Europe: The relationship between motivation and entry mode choice. In A. Risberg, D. King, \& O. Meglio (Eds), The Routledge companion to mergers and acquisitions. London: Routledge.

Schmitz, H. 2006. Regional systems and global chains. Mimeo, IDS, Sussex.

UNCTAD. 2014. World Investment Report 2013: Global Value Chains. Geneva: UNCTAD.

\section{Endnotes}

1 The main data sources of EMENDATA are: fDiMarkets from the Financial Times providing information on greenfield investments, Zephyr from the Bureau van Dijk (BvD) and SDC Platinum from Thomson Reuters both collecting data on Mergers and Acquisitions and other minority investments. EMENDATA provides information at the level of the single deal, of the investing company and of the global ultimate owner (GUO).

2 The research project has been funded by Riksbankens Jubileumfond in the framework of Europe and Global Challenges program. A detailed presentation of the main findings of the research project is available at https://globalisationofinnovation.files.wordpress.com/2015/03/tfdi-byemerging-multinationals-in-europe.pdf

3 The weight of Europe on Chinese and Indian outward investments corresponds to one third of their global investments.

4 Proxied by the share of intangible assets to total assets of the investor.

5 Piscitello et al (2014) reach this conclusion with content analysis on the motivations of the acquisitions, as they appear on the basis of companies' public announcements published in Lexis-Nexis.

6 Based on interviews undertaken by Balaji Parthasarathy, Ju Liu, Teis Hansen, Cristina Chaminade and Rasjesh Mishra.

7 An overview of the different impacts based on the case studies can be found in Chaminade et al (forthcoming).
8 Cross-border inventions are identified considering all patents, whose inventive teams are composed by Brazilian, Indian and Chinese (BIC) inventors and at least one EU inventor; domestic patents are those whose inventive team is composed only of inventors from the individual BIC countries (e.g. for Chinese collaborations only Chinese inventors).

9 In the questionnaire, world leading innovation is defined as the ability to introduce product and process changes based on world-class R\&D that advances the technological frontier and helps to establish new trajectories of technological change. Intermediate innovation is defined as the ability to introduce changes which are mostly adaptations to product and process technologies based on design and engineering activities, rather than systematic $R \& D$

Cristina Chaminade is a full professor in Innovation Studies at Lund University. She holds a doctoral degree in Economics from the Autonomous University of Madrid. Her area of expertise is in globalization of innovation, particularly in global innovation networks and innovation in emerging economies. She has actively worked on innovation in developing countries for over 15 years. She's been advisor of international organizations such as the European Commission, UNCTAD, OECD and UN-ECLAC. She has published in international journals, refereed books and handbooks in the fields of innovation, development studies and knowledge management.

Roberta Rabellotti is Professor of Economics in the Department of Political and Social Sciences at the Università di Pavia in Italy. She has a Master of Science in Development Economics at the University of Oxford and a Doctor of Philosophy at the Institute of Development Studies, University of Sussex. Her publications include books with Harvard University Press, Edward Elgar and Macmillan as well as numerous articles published in top academic journals. Her main research interests are in the field of development and innovation. Prof. Rabellotti regularly advises international organizations such as UNIDO, UNCTAD, IADB, OECD and the European Commission on questions related to economic development. 